\title{
Faggot Speaks: A Poetic Inquiry into the Experience of \\ Antigay Mistreatment and Sexual Prejudice
}

\author{
Silvio Machado ${ }^{1}$ \\ The Sanville Institute/Private Practice \\ Berkeley, CA USA \\ S.Machado.PhD@gmail.com
}

\begin{abstract}
Research suggests that, compared to heterosexual counterparts, gay men and other sexual minorities are at higher risk of developing emotional distress and mental disorders. The sexual minority stress model attributes these health disparities to the chronic social stress that arises in response to exposure to antigay mistreatment and sexual prejudice pervasive in the culture. Little research has been done to illuminate the lived experience of exposure to prejudiced behaviors and attitudes and this inquiry aims to begin to fill this gap by addressing the following questions: What is the experience of being mistreated for being gay or perceived as gay? What is the experience of being exposed to sexual prejudice when one is gay? Using the writing of autobiographical poetry as a process of inquiry and the resulting poems as narrative data, I explore my own experiences with antigay encounters and sexual prejudice over the course of my life. The intent is to vivify and magnify the phenomenon under investigation via evocative poetic renderings aimed to foster empathy and embodied understanding in the reader.
\end{abstract}

Key Words: Gay, Homophobia, Sexual Prejudice, Poetic Inquiry, Autobiographical Poetry, Autoethnography

\footnotetext{
${ }^{1}$ Biographical Statement: Silvio Machado is on the core faculty at the Sanville Institute for Clinical Social Work and Psychotherapy and adjunct faculty in the Department of Counseling at Sonoma State University and the Department of Psychology at Meridian University. His research interests include depth psychologies and psychotherapies and their application to sexual minority issues. He draws extensively from arts-based approaches to research and has presented his work nationally. In addition to teaching, Silvio maintains a private psychotherapy practice in Northern California, where he specializes in working with individuals with trauma-, mood-, and anxiety-related issues.
} 
A large body of research demonstrates higher rates of emotional distress and mental disorders among gay men and other sexual minorities (e.g., Cochran \& Mays, 2007; Case et al., 2004; Thoma \& Huebner, 2013). These negative health outcomes have been linked to the social stress that comes with being gay, particularly to exposure to various types of antigay mistreatment and sexual prejudice. Although this research is critical to clinical psychology, thick descriptions of the experience of being the target of sexual prejudice and antigay discrimination-arguably the most significant types of stressors gay men face-are just as critical, yet sorely lacking. I find these thick descriptions in my psychotherapy practice where I primarily work with sexual minority men. Clients frequently share stories about past and current traumatic mistreatment and how these affect them. As a gay man myself, I too have stories and, I suppose, my own painful experiences with homophobia, at least in part, called me to the work of psychotherapy.

In this poetic inquiry, I explore the following questions: What is the experience of being mistreated for being gay or perceived as gay? What is the experience of being exposed to sexual prejudice when one is gay? Using the writing of autobiographical poetry as a process of inquiry and the resulting poems as narrative data (Furman, 2003, 2004a, 2004b; Gallardo, Furman, \& Kulkarni, 2009), I explore my own experiences with antigay encounters and sexual prejudice over the course of my life. In the spirit of poetic inquiry, which has become an established method in qualitative research across disciplines (e.g., Brady, 2004; Burdick, 2011; Furman, Leitz, \& Langer, 2006), the goal of this research is not generalizable definitive assumptions, but narrative truths that illuminate and vivify the phenomenon under investigation in an emotionally evocative way.

A word about terms is warranted here. For the purposes of this inquiry, I use the terms discrimination, antigay mistreatment, and prejudiced behaviors interchangeably to refer to the behavior of aggressors. When referring to negative attitudes about nonheterosexual sexual orientation, I use the terms sexual prejudice or antigay attitudes. It is also important to note that antigay mistreatment and sexual prejudice arise in many social and relational contexts. For the purposes of this inquiry, I consider experiences with peers, family members, and strangers involving verbal assaults, threats, rejection, and negative reactions to, and discomfort with, my sexual orientation.

\section{The Effects of Antigay Mistreatment and Sexual Prejudice}

This inquiry is framed by the literature below on mental health outcomes and emotional distress in sexual minority populations, the prevalence of sexual prejudice and antigay mistreatment, and the link between antigay mistreatment and emotional distress.

Population-based, epidemiological research consistently shows that gay men and other sexual minorities are at greater risk for a range of poor mental health outcomes (e.g., Cochran \& Mays, 2007; Case et al., 2004; Thoma \& Huebner, 2013). Sexual minorities are more likely to experience depression (Cochran \& Mays, 2006; 
Thoma \& Huebner, 2013), panic disorder (Cochran, Sullivan, \& Mays, 2003), posttraumatic stress (Gilman et al., 2001), and anxiety (Cochran \& Mays, 2006; Jorm, Korten, Rodgers, Jacomb, \& Christensen, 2002; Sandfort, de Graaf, Van Bijl, \& Schnabel, 2001). Increased rates of hopelessness and low self-esteem (Plöderl \& Fartacek, 2005) and lower rates of social support (Eisenberg \& Resnick, 2006; Safren \& Heimberg, 1999) have also been found. Compared to heterosexual peers, sexual minority adolescents are at least six times more likely to suffer with multiple mental health diagnoses (Fergusson, Horwood, \& Beautrais, 1999). Increased rates of alcohol and substance abuse and dependence have also been found among gay men and other sexual minority adults and adolescents (Cochran \& Mays, 2006; Sandfort, Bakker, Schellevis, \& Vanwesenbeeck, 2006; Thoma \& Huebner, 2013). Research also shows disparities related to suicidal behavior. Gay men and other sexual minorities experience higher rates of suicidal ideation, planning, and attempts compared to heterosexual peers (Burton, Marshal, Chisolm, Sucato, Friedman, 2013; de Graaf, Sandfort, \& ten Have, 2006; Hatzenbuehler, 2011).

As diPlacido (1998) noted, discrimination and exposure to antigay attitudes can range from the daily frustrations that gay men face such as the assumption of heterosexuality, to significant events such as family rejection or physical assault. In a survey conducted by the Kaiser Family Foundation (2001), 32\% of sexual minority respondents reported that they had experienced physical violence or damage to their personal property on account of their sexual orientation. Seventy-four percent reported that they had experienced verbal abuse, while 55\% reported that they, or someone they knew, had been discriminated against on the job. Respondents in a different representative sample were two times as likely to report experiences of discrimination compared to heterosexual respondents (Mays \& Cochran, 2001). Discrimination in this study included a range of violations, from being denied a scholarship to being harassed by police. Herek (2009) found that approximately $38 \%$ of gay men from a representative sample reported experiencing anti-gay property damage and physical violence at least twice in their lives.

More recently, the largest survey of lesbian, gay, bisexual, and transgender individuals (European Union Fundamental Rights Agency, 2013) was carried out in the European Union to learn more about discrimination, violence, and harassment based on sexual orientation or gender identity. Over half of the 93,000 respondents reported experiences of discrimination in the past year and $90 \%$ of them did not report these incidents to law enforcement. Half of respondents reported avoiding public places out of fear of being targeted, while over $65 \%$ of respondents avoided holding hands in public with their partners. Over $80 \%$ reported hearing antigay jokes or slurs regularly, while $20 \%$ reported having experienced discrimination at work or while looking for a job.

Several studies in the sexual minority stress literature specifically focus on the relationship between antigay mistreatment or the expectation of mistreatment (i.e., 
perceived stigma) and emotional distress. As described above, discrimination refers to a variety of actions or behaviors. Antigay mistreatment can be obvious, as in the case of physical assaults, and institutionalized, as in the case of sodomy laws or amendments banning same-sex marriage. A number of researchers (D'Augelli \& Grossman, 2001; Herek, Gillis, \& Cogan, 1999; Scales Rostosky, Riggle, Horne, \& Miller, 2009) have explored the impact of various forms of discrimination and antigay mistreatment.

Herek, Gillis, and Cogan (1999) studied the effects of antigay physical and sexual assault, robbery, and vandalism on the mental health of 2,259 sexual minority men and women. They found that victimization was associated with higher rates of distress, specifically depression, traumatic stress, anxiety, and anger. Respondents who had endured violence were significantly more likely to view the world as unsafe, regard other people as malevolent, to show a relatively low sense of personal mastery, and to attribute personal difficulties to prejudice. Two studies on the effects of antigay verbal and physical victimization (Almeida, Johnson, Corliss, Molnar, \& Azrael, 2009; D’Augelli \& Grossman, 2001) found that respondents who endured physical violence had significantly lower self-esteem and higher rates of suicide-related internalized homophobia and past suicide attempts. Hatzenbuehler, Nolen-Hoeksema, and Erickson (2008) examined the effects of antigay discrimination and perceived stigma on a small sample of AIDS-bereaved gay men. Results showed that discrimination and drug use were positively correlated, while perceived stigma was associated with higher rates of depression.

Perceived stigma, or the anticipation of mistreatment, is pervasive in the lives of gay men and other sexual minorities. Perceived stigma often results from an individual's direct experience with antigay mistreatment or exposure to sexual prejudice; however, it can also be reinforced vicariously. If, for example, a gay man hears about a gay bashing, he may question his own safety and may be extra cautious when he leaves his home out of fear of being victimized as well. Mays and Cochran (2001) found that, compared to heterosexuals, sexual minorities were approximately four times more likely to perceive others thinking less of them and three times more likely to perceive others fearing them. In his frequently cited study of 741 gay men, Meyer (1995) found that antigay mistreatment and perceived stigma were associated with demoralization, guilt, and suicidal ideation. More recently Hatzenbuehler, Nolen-Hoeksema, and Erickson (2008) found that the anticipation of mistreatment was associated with depressive symptoms.

Prior to the removal of homosexuality from the Diagnostic and Statistical Manual of Mental Disorders (American Psychiatric Association, 1973), higher rates of emotional distress and mental disorders were attributed to homosexuality itself. However, it is now clear that these higher rates among gay men are better understood in the context of the chronic and pervasive social stress that comes with underprivileged status in a predominantly heteronormative and heterosexist culture (Meyer, 1995, 2003). The sexual minority stress literature provides a framework for understanding the impact of exposure to sexual prejudice and antigay mistreatment on gay men. The model assumes that in occupying a disadvantaged social status, one faces excessive social stressors (Meyer, Schwartz, \& Frost, 2008) and may have limited access to coping 
resources (Brooks, 1981). As others have noted, minority status comes with disproportionate exposure to stress-arousing features of society, which have a profound effect on stigmatized and underprivileged groups (Jones et al., 1984; Thoits, 1999). Hatzenbuehler (2009) provided a mediation framework for understanding the link between exposure to sexual minority stressors and mental disorders. According to his model,

sexual minorities confront increased stress exposure resulting from stigma; this stigma-related stress creates elevations in general emotion dysregulation, social/interpersonal problems, and cognitive processes conferring risk for psychopathology; and these processes in turn mediate the relationship between stigma-related stress and psychopathology. (p. 707)

In one sense, this inquiry provides a personal, intimate illustration of Hatzenbuehler's (2009) model by describing the lived experience of exposure to stigma-related stress in the form of prejudiced behaviors and attitudes.

The above research suggests that antigay mistreatment, the anticipation of mistreatment, and exposure to sexual prejudice are common experiences for gay men and other sexual minorities. Further it is clear that such exposure to prejudiced behavior is associated with a host of negative health outcomes that are likely mediated by the understandable emotional and cognitive responses to such encounters. What remains unclear from these empirical findings are the lived experiences of those who have endured negative treatment. The aim of this inquiry is to illuminate the texture of that lived experience via autobiographical poetic renderings. This method is further described below.

\section{Poetic Inquiry}

Poetic inquiry has received a great deal of attention in the qualitative research literature. In the broadest sense, poetic inquiry refers to research involving poetry in some manner. Poetry can help the researcher evoke meaning and poignancy in narratives. According to Leavy (2009), poetry's attention to space, rhythm, silence, and words creates a feeling picture that contains a "snippet of human experience that is artistically expressed as in a heightened state" (p. 64), which can be used to show, in an evocative way, how it is to live the phenomenon under investigation (Richardson, 2002). Poet-researchers use emotionality as a tool to sharpen the reader's focus on what is affective, potent, and essential. For many poet-researchers, emotional poignancy is the goal of research poetry (e.g., Carr, 2003; Langer \& Furman, 2004), as it allows the reader to receive the data in a new, embodied, and exciting way. As Richardson (1994) stated, poems 
concretize emotions, feelings and moods - the more private kind of feelings - so as to recreate the experience itself to another person. A lyric poem "shows" another person how it is to feel something. Even if the mind resists, the body responds to poetry. It is felt. To paraphrase Frost, poetry is the shortest emotional path between two people. (p. 9)

Krøjer and Hølge-Hazelton (2008) echoed this point, stating that poetic representations in research allow emotions to become essential to understanding what the text uncovers.

The use of autobiographical poetry to explore the experiences of underprivileged populations can be seen as an emancipatory act. This notion aligns with feminist (Hesse-Biber, 2013), indigenous (Kovach, 2010), performative (Pelias, 2005), and queer (Browne \& Nash, 2010) methodological assumptions. In this inquiry, I am empowered to speak as a gay man about my experiences of being mistreated for being gay without feeling compelled to aim for a value-free, sterile research production. Rather than subduing the data and, by extension myself, in a hygienic mannersomething that often occurs in more traditional forms of qualitative research resulting in the removal of the experiencing subject-the use of autobiographical poetry allows me to magnify and vivify the phenomenon under investigation. As Pelias (2005) emphasized, personal experiences are innately political and, when told in a performative manner, reveal something about the contexts in which they occur.

By engaging in an artful telling of these experiences, I believe that I transform their meaning and lessen the pain they carry. Autobiographical poetry as a method of inquiry blurs the line between research and personal transformation in this way, and allows me, and the meaning I derive from experience, to be changed by the research process. The therapeutic value of poetry has been well documented (Mazza, 2003). Fox (1997) describes poetry's mutative potential:

Poetry helps us feel our lives rather than be numb. The page, touched with our poem, becomes a place for painful feelings to be held, explored and transformed. Writing and reading poems is a way of naming where we have been, where we are, and where we are going in our lives. (p. 3)

Furman $(2003,2004 b)$ illustrates this grey area when he uses poems written for selftherapy to illustrate the transition to stepfatherhood and the experience of friendship loss.

To carry out this inquiry, I began by recalling personal experiences with sexual prejudice and antigay mistreatment. Focusing on one occurrence at a time, over a fivemonth period, I crafted seven poems, presented chronologically below, that describe the lived experience of these encounters, with the intention of developing evocative renderings that capture "the hues, [and] the textures" (Glesne, 1997, p. 206) of each experience. Then, after the poems were written, I engaged with each one in an iterative process of reflective editing. During periods of reflection, my aim was to elaborate the emerging meanings in each poem and, where appropriate, resulting insights about my 
experience were added to the poems. During periods of editing, I focused on the poetics of each poem, with an emphasis on sound use of poetic devices to amplify and elaborate the narrative contained in each rendering. The final step in the process involved writing brief narrative reflections to contextualize each poem. In these reflections, I explored how I now relate to the experiences, as they are mediated by the poems, and touch on the transformative arc the creation of the poems permitted. These reflections are the basis for the material below that frames each poem.

\section{The Poems}

My first encounter with antigay sentiment was in kindergarten, when, on Halloween, a classmate called me a faggot. This was the first time I had ever heard the word and, although I did not understand its meaning, I felt diminished by it nonetheless. The poem Good Word describes this experience, starting with a quote by poet David Whyte on the power of words to nourish, and moving through the way in which "other words" have the power to starve, reduce, and stigmatize.

\section{Good Word}

People are hungry and one good word is bread for a thousand. --David Whyte ${ }^{2}$

i.

But other words are deadening.

Other words cut the skin, taste like poison in the mouth and starve.

They jar the ear and when spoken, regardless of tone, diminish.

Some words are fatal.

Some, with no more than two syllables, fragment lives, scattering a lifetime-however long or short-like ashes.

Some words should never be spoken, not because they're offensive,

but because of the dark manna they carry.

${ }^{2}$ Whyte, D. (1996). The house of belonging. Langley, WA: Many Rivers Press. 
ii.

Once my bandana was on my head I left the house.

Patch on eye, plastic sword in hand,

clip-on hoop earring on ear-it was Halloween

and I was off to kindergarten dressed as a pirate, ripe with anticipation for the holiday.

When I arrived to morning circle,

Mrs. Nemens called role. I had no choice

but to sit next to Donald. He was the class bully, with a grating, raspy voice and uncontained fire

in shadowy eyes.

Hey faggot, he said, Nice faggot earring.

I had never heard the word before

nor felt the sting it carried.

He choked it out, trying

not to gag on its putrid taste.

It landed on my cheek, running down,

like a thick wad of saliva I couldn't wipe away.

It spread-an angry rash-down my jaw,

up my tiny brow. I hid my face the rest of the day,

somehow knowing no one could know.

I wrestled in silence with this new word,

the mystery of its weight, the long swoop

of the first syllable-faaaaaaaa-

and the sharp cut of the last - gut.

iii.

Some words annihilate.

Some shame, like a red disease.

Some words drop bombs, while others spray good people in the streets with fire hoses.

Some get into the skin like a splinter and, no matter the finesse, cannot be removed.

They infect. They turn bitter in the blood.

They fester.

iv.

My mind raced. 
I repeated the word like a mantra

trying to decipher its meaning.

That night I lay in bed, feverish, a lead weight upon my chest.

Inside I burned like an effigy,

that is to say, an approximation

of a person.

As the poem conveys, being called a faggot for the first time left me reeling. I see now in hindsight, two layers of shame. First, although I know that the incident had nothing to do with my actual sexual orientation-or anything about me, for that matterat the time I felt as though something terribly shameful about me, though I could not say what, had been exposed. Second, as the poem illustrates, I felt ashamed for being targeted and paralyzed to do anything about it aside from ruminating in isolation on the experience in an attempt to understand it. This experience was the first of many to come in which I would be called a faggot, another of which is detailed below in the poem Stranger.

In writing Good Word, I reach back in time to my young, alienated self and voice on behalf of that boy the impact of the encounter. This is something I was not able to do at the time. I see in the poem very clearly the power that words have. I describe the "dark manna" of the word faggot by using words-words that now nourish me with the truth they carry. The words of this poem connect me to a sociohistorical fabric of alienated and stigmatized others who have also been poisoned by oppressive words. In so doing, the poem undermines my otherness.

When I was 17-years-old I told my mother I was gay and, shortly thereafter, my mother told my father. My family entered into a difficult period of turmoil referred to in the literature as the family disclosure crisis (Beeler \& DiProva, 1999; DeVine, 1984). Initial parental reactions to the news of a child's non-heterosexual sexual orientation are usually negative (Ben-Ari, 1995; Cramer \& Roach, 1988; Patterson, 2000). Negative reactions from family members can be understood in terms of sexual prejudice since they are based on the individual's sexual orientation and misconceptions family members have about it. The following two poems explore two poignant moments during this crisis period in which I was faced with my parents' sexual prejudice. 
She sat at the table palms to the placemat. It was almost peaceful, her pillowy hips spilling over the edges of the chair. Her face was stiff, expressionless, but knowing now what she could not un-know, a mask pulled tight against the bones of her face. Suddenly I realized it was anger I was reading when she set her closely set eyes upon me.

Maybe she wanted to puke. Or like Saturn, maybe she wanted to swallow me whole.

Maybe she wished I had kept this to myself or, in that moment, that she had given birth to a different son.

Finally she spoke:

This lifestyle is a choice you're making.

You need to know

I will never accept it.

I will love the sinner

but not the sin.

It happened suddenly. With those words, spoken like an incantation, I stood in the shadow of her icy backside.

I called a friend and told her I didn't recognize my mother anymore.

The mother I knew was gone and I had no idea how to live under this new woman's roof. That night I packed a bag and kept it in my trunk.

A hidden pair of car keys glimmered in the moonlight out in the yard.

One day, if I needed to, I would be ready. 
I would disappear.

In this and the following poem, I attempt to capture the precise moment I felt my relationship with my parents slip through my hands. I remember how quickly it seemed to happen-suddenly I felt like they no longer knew me and that I could no longer trust them.

\section{My Father Says We Can Pray}

The wind howled all night.

Come morning, he stood at the foot of my bed, tapped my leg and woke me.

Come on, we're going to the beach.

We have some things to let go of.

We drove the winding roads in silence through dense walls of fog.

Along the way the large bodies of eucalyptus trees lay toppled. The pressure between us rose, until finally we arrived at the coast where sunlight was breaking through in streams out on the water.

The patches of Marram grass whipped wildly in the bluster and a gust of sandsweep put its hand to our chests as we made it out of the dunes. He spoke, We can pray, he said, We can pray and God will change you.

This is not who you are. He looked frantic, his eyes wide as if waking from a nightmare.

This is my fault, he said, I know it.

I don't think there was

a single word in any language

that could have helped.

There was no reaching himhe was crippled by the information he could not now un-know. We stood at land's edge, my father and I, and suddenly we forgot how to touch each other. 
The father-son tether frayed, each of us at either end.

We were strangers, separated by the cold fingers of the wind, and the news of my homosexual lifestyle.

When he said we have some things

to let go of, neither of us imagined

this is how it would be.

There we stood, our hearts

like trapped animals.

We'll pray to Fathima, he said,

And you will be healed.

The wind tore through the whitewash, dashed sand in our eyes.

You will be healed, he said, tears and sand on our faces,

Healed for good.

Writing these two poems, I recall feeling like my world was unraveling. That day on the beach I remember thinking - perhaps hoping - that one day I would chronicle that moment between my father and me in a poem that would translate the pain between us into something beautiful. Using each poem as a lens through which to view these experiences, I feel the existential poignancy of the profound separation that can occur suddenly between parent and child. I wanted my parents to change their values just as much as they wanted me to change my sexual orientation. This conflict was heightened by the fact that each of us knew that we loved each other. How could I do this to them? How could they do this to me? And how could we do this to each other, all in the name of love.

Whereas the poems above detail my experience with antigay mistreatment and sexual prejudice with known peers and family members, the following three poems address experiences with strangers.

\section{Stranger}

Suddenly I think of you. I realize

I don't know anything about you, I don't know

your name, where you live, where you grew up.

I cannot name you, as one names his accuser,

in open court, as I would like to do

in the lines of this poem,

so that it somehow forms a testament

to what I experienced that day. All I know is this:

I was eighteen years old and the air was blooming

with spring. My boyfriend and I sat on a park bench together

and feeling tender, I put my hand on his knee 
just for a moment.

I didn't see you passing by, not until I heard the words, Fuckin' Faggots.

I should kick your asses for that shit.

I looked up and there you stood.

I took in the thin line of your form-feet to head-

my eyes traveling toward your gaze,

which hung like a threat in the air,

a loaded gun. I don't remember

what happened next, but I remember the fear

spreading through my body like a quick-moving palsy.

That night my boyfriend and I made love

in a hotel bed. I prayed the taste of his skin

would quiet the fear, which clung like a newborn's caul

and could not be shaken. I remember

thinking you were there with us, a third body-

daddy longlegs - hovering on the ceiling above the bed,

looming, waiting-

I even thought I heard you breathing

in the silences between my breath,

his breath,

and the places they parted

and came together.

Stranger holds a powerful paradox for me. On one hand, the encounter felt deeply impersonal. I did not know this man, nor did he know me. The emotional distance allowed him to objectify and dehumanize us. In hindsight, the fact that the assailant was a stranger was in great part what made the event so disturbing to me. Suddenly the world felt unsafe to me. Without knowing us, this man threatened my boyfriend and me with incredible malice. On the other hand, the experience felt incredibly personal. This stranger witnessed an intimate, loving moment between my boyfriend and me and, as a result, was a part of that moment. Further, despite my best efforts, the experience got under my skin and, as the poem describes, invaded my most personal moments and "could not be shaken" for weeks afterwards.

Stranger describes one of the more frightening experiences with verbal harassment I have had, and one of the first times such an experience was perpetrated by someone I did not know. Although my boyfriend and I were not physically attacked, our safety was threatened by the actions of the assailant. In this poem and the poem below, I convey the traumatic reverberations that often result from antigay encounters. This traumatic quality was characterized by intense preoccupations with my own safety 
after the event and, as in the experience detailed in the poem below, after being exposed to the horrifying news of Matthew Shepherd's deadly encounter with homophobia.

\section{To Aaron McKinney \& Russell Henderson}

I was seventeen years old when you killed him. He died October 12, 1998, but October 6 was the night it all happened. The way I pictured it a gibbous moon hung close to the horizon, offering strange comforta place he could imagine himselfas he drifted in and out of consciousness, his broken body, strung to the fence like a scarecrow, for eighteen icy hours. I read the headline: Gay College Student Dies after Laramie Attack, and my nerves went numb. My heart split like a stone and the dark hand of griefor was it fear?-clutched the back of my tongue, closing my throat.

You were over a thousand miles and three states away, and yet the thought of you, and others like you, terrified me. I turned corners with caution.

My mind spun like a movie reel, playing and replaying

all the times I was called a faggot, all the times I was shoved in the hallways at school, all that times I feared for my safety. I succumbed to the idea that one day, I might be killed, made an example of and left for dead. I realized that I was just as susceptible, that I could be disappeared into the night only to become a headline.

I imagined how it would go with me, I couldn't stop it. Everywhere I went, I chewed on questions:

Would you blindfold me? Bind my wrists?

Would you know my name before the dull blow to the back of my head? Would I beg for my life?

Tell you I would do anything? Would I smell the dry grasses of Indian Summer, amidst the brick-a-brac of that remote scenea torn mattress, broken bottles, a pile of dirty clothesas I lay there? Would the moonlight for some brief moment, fall upon my face before it finally goes dark? And, come morning, would my body dissolve 
into the cold earth, as they say, ashes to ashes, dust to dust?

To Aaon McKinney and Russell Henderson also explores the paradox mentioned regarding Stranger, but as it occurs in vicarious trauma. I did not know Matthew Shepherd, so in one sense the experience of his death was impersonal. Yet simultaneously, I could relate to the type of hatred that resulted in his death and, in that way, his death was deeply personal, and reverberated with me long after it occurred.

As an adult, I encounter blatant antigay mistreatment and sexual prejudice much less frequently in my day-to-day life. After several difficult years of strain between us, my parents and I have mended our relationship and they fully accept and celebrate having a gay son. For years I have been employed in various settings (e.g., AIDS service and LGBT youth organizations) in which my sexual orientation and the sensitivity to the sexual identities of others that it brings has been an asset. As mentioned above, I currently work in my psychotherapy practice with gay men and other sexual minorities who have intentionally sought an openly gay therapist. Nonetheless, heterosexist and heteronormative attitudes pervade our culture and arise from time to time. I still encounter individuals who, when they learn I am gay, appear rather uncomfortable in my presence. The poem Familiar Meeting describes a relatively recent experience like this.

\section{Familiar Meeting}

The man greets my mother with a kiss on the cheek.

Looking at him, I can't tell where his neck ends and his head begins.

My mother says, This is my son, Silvio, and his husband, Michael.

The smile on his face tightens like stretched canvas. I have seen it a thousand times before: the friendly smile turned forced grin. He makes no eye contact as he shakes our hands. He kicks a pebble with his shoe. I read the behavior as one reads clouds or the migration patterns of birds to predict what comes next.

He attempts to regain composure. 
but flubs his words. I imagine

this meeting without the common link

of my mother, say, if he saw us walking

down the street holding hands.

I imagine how, under different circumstances,

this familiar meeting

with this familiar stranger

might be familiar

in a very different way.

In Familiar Meeting I see how my current encounters with sexual prejudice are shaped by past experiences. Not only does the poem capture the awkward moment with my mother's friend, it illustrates the way in which such an experience conjures to mind for me a whole range of possible outcomes under different circumstances. I see in the poem my own hypervigilance-the keen sensitivity I have developed to the feeling states of others when it comes to my sexual orientation.

\section{Closing Reflections}

Increased visibility of the gay community appears to be having a slow but positive effect on social attitudes toward gay men and other sexual minorities. Polls in the United States between 1977 and 2004 reveal that attitudes toward homosexuality and samesex relationships have become more tolerant (Avery et al., 2007). Despite these hopeful trends, homophobia, heterosexism, discrimination, harassment, and physical violence against sexual minorities prevail. Well-known tragedies such as the suicides of Seth Walsh, Asher Brown, and Tyler Clementi-all victims of antigay bullying-illustrate the often-lethal outcomes of intolerance. Research suggests that gay men and other sexual minorities face higher rates of emotional distress and mental disorders. The sexual minority stress model (Meyer, 1995, 2003) explains these disparities in terms of the chronic, pervasive social stress sexual minorities face. Exposure to chronic stress may result in emotional dysregulation and interpersonal problems that increase risk for poor mental health outcomes (Hatzenbuehler, 2009).

Rather than focusing on mental health outcomes, the purpose of this inquiry is to probe and magnify the affective nature of the experience of being the target of antigay mistreatment and sexual prejudice. Nonetheless, there are important points of convergence between the literature on emotional distress resulting from discrimination and the poetry comprising the findings of this inquiry. For example, the poem Good Word illustrates the demoralization and depression that often results from antigay mistreatment and perceived stigma (Meyer, 1995). Although I did not understand the meaning of the word faggot when my classmate used it, I experienced a tremendous sense of shame that left me feeling diminished, like "an approximation of a person." The two poems Stranger and To Aaron McKinney \& Russell Henderson illuminate the traumatic reverberations and anxiety that often come with the experience of being the target of antigay mistreatment (Herek, Gillis, \& Cogan, 1999). I was shaken by these 
direct and vicarious traumatic incidents, troubled by intrusive thoughts and hypervigilance, and only after several weeks did their impact lessen.

The literature suggests that sexual minorities who have been the target of antigay mistreatment or sexual prejudice are more likely to perceive the world as unsafe (Herek, Gillis, \& Cogan, 1999) and to perceive others thinking less of them (Mays \& Cochran, 2001). The poem My Mother at the Table illustrates this process. The poem describes the abrupt transition in my experience of my mother as someone I could trust to someone about whom I needed to be wary. The unraveling of this relationship, and my relationship with my father described in the poem My Father Says We Can Pray, left a strong sense of insecurity about the world that pervaded much of my late adolescence and early adulthood. How could I trust the world if I could not trust my parents? This wariness and caution is also present in the poem Familiar Meeting, which details a recent experience with someone's obvious discomfort with my relationship with my partner.

I hope this inquiry also demonstrates some of the benefits of using autobiographical poetry in research, which I will briefly mention here in reference to the above poems. First, the poems vivify narratives that might otherwise become sterilized and subdued in more traditional forms of qualitative research. The aim here is to create a feeling picture, not a thematic analysis. Second, the poems convey complex emotional nuances via affectively charged imagery intended to evoke an embodied, emotional response. I hope this either fosters a sense of empathy in the heterosexual reader that can be used to sensitize him or her to the experiences of gay men and other sexual minorities, or perhaps resonates with the sexual minority reader in a way that affirms a shared experience. Third, the use of autobiographical poetry here has political, emancipatory implications. I am free as a poet-researcher to voice my experience of being a gay man without the fear of being silenced as I have in the past. I present my experience in a form that brings together the scientific and artistic aspects of myself without apology, or having to privilege one over the other.

Finally, by describing them in crafted form, I transform these painful experiences into aesthetic, artful renderings. Writing autobiographical poetry about my encounters with antigay mistreatment and sexual prejudice requires that I reflect on emotional, and at times traumatic occurrences, in a thoughtful, reflexive manner so as to convey accurately both the internal experiences and external circumstances involved. In constructing these poems, something mutative has occurred for me in the process, whereby I am able to hold these experiences, and the shame they instilled, in compassionate awareness, knowing they do not define who I am. This notion aligns with Wordsworth's (2001/1800) definition of poetry, which he states, "takes its origin from emotion recollected in tranquility" (para. 26). 


\section{References}

Almeida, J., Johnson, R., Corliss, H., Molnar, B., \& Azrael, D. (2009). Emotional distress among LGBT youth: The influence of perceived discrimination based on sexual orientation. Journal of Youth and Adolescence, 38(7), 1001-1014.

American Psychiatric Association. (1973). Diagnostic and statistical manual of mental disorders $\left(2^{\text {nd }}\right.$ ed. $)$. Washington, DC: Author.

Avery, A., Chase, J., Johansson, L., Litvak, S., Montero, D., \& Wydra, M. (2007). America's changing attitudes toward homosexuality, civil unions, and samegender marriage: 1977-2004. Social Work, 52(1), 71-79.

Beeler, J., \& DiProva, V. (1999). Family adjustment following disclosure of homosexuality by a member: Themes discerned in narrative accounts. Journal of Marital and Family Therapy, 25(4), 443-459.

Ben-Ari, A. (1995). The discovery that an offspring is gay: Parents', gay men's, and lesbians' perspectives. Journal of Homosexuality, 30(1), 89-112.

Brady, I. (2004). In defense of the sensual: Meaning construction in ethnography and poetics. Qualitative Inquiry, 10(4), 622-644.

Brooks, V. R. (1981). Minority stress and lesbian women. Lexington, MA: DC Health.

Browne, K., \& Nash, C. J. (2010). Queer methods and methodologies: Intersecting queer theories and social science research. Burlington, VT: Ashgate Publishing Company.

Burdick, M. (2011). Research and teacher-participant found poetry: Collaboration in poetic transcription. International Journal of Education \& the Arts, 12. Retrieved from: http://www.ijea.org/v12si1/.

Burton, C. M., Marshal, M. P., Chisolm, D. J., Sucato, G. S., \& Friedman, M. S. (2013). Sexual minority-related victimization as a mediator of mental health disparities in sexual minority youth: A longitudinal analysis. Journal of Youth and Adolescence, 42(3), 394-402. doi: 10.1007/s10964-012-9901-5

Carr, J. M. (2003). Poetic expressions of vigilance. Qualitative Health Research, 13(9), 1324-1331.

Case, P., Austin, B., Hunter, D. J., Manson, J. E., Malspeis, S., Willett, W. C., \& Spiegelman, D. (2004). Sexual orientation, health risk factors, and physical functioning in the Nurse's Health Study II. Journal of Women's Health, 13(9), 1033-1047. 
Cochran, S. D., \& Mays, V. M. (2006). Estimating prevalence of mental and substanceusing disorders among lesbians and gay men from existing national health data. In A. M. Omoto \& Kurtzman, H. S. (Eds.), Sexual orientation and mental health: Examining identity and development in lesbian, gay, and bisexual people (pp. 143-165). Washington, DC: American Psychological Association.

Cochran, S. D., \& Mays, V. M. (2007). Physical health complaints among lesbians, gay men, and bisexual and homosexually experienced heterosexual individuals: Results from the California Quality of Life Survey. American Journal of Public Health, 97(11), 2048-2055.

Cochran, S. D., Sullivan, J. G., \& Mays, V. M. (2003). Prevalence of mental disorders, psychological distress, and mental health services use among lesbian, gay, and bisexual adults in the United States. Journal of Consulting and Clinical Psychology, 71(1), 53-61.

Cramer, D., \& Roach, A. (1988). Coming out to mom and dad: A study of gay males and their relationships with their parents. Journal of Homosexuality, 15(3/4), 79-91.

D’Augelli, A. R. \& Grossman, A. H. (2001). Disclosure of sexual orientation, victimization, and mental health among lesbian, gay, and bisexual older adults. Journal of Interpersonal Violence, 16(10), 1008-1027.

de Graaf, R., Sandfort, T. G. M., \& ten Have, M. (2006). Suicidality and sexual orientation: Differences between men and women in a general population-based sample from the Netherlands. Archives of Sexual Behavior, 35(3), 253-262. doi: $10.1007 / \mathrm{s} 10508-006-0920-\mathrm{z}$

DeVine, J. L. (1984). A systemic inspection of affectional preference orientation and the family of origin. Journal of Social Work and Human Sexuality, 2(2-3), 9-17.

DiPlacido, J. (1998). Minority stress among lesbians, gay men, and bisexuals: A consequence of heterosexism, homophobia, and stigmatization. In G. M. Herek (Ed.), Stigma and sexual orientation: Vol. 4 Understanding prejudice against lesbians, gay men, and bisexuals (pp. 138-159). Thousand Oaks, CA: Sage.

Eisenberg, M. E., \& Resnick, M. D. (2006). Suicidality among gay, lesbian, and bisexual youth: The role of protective factors. Journal of Adolescent Health, 39(5), 662668.

European Union Agency for Fundamental Rights. (2013). European Union lesbian, gay, bisexual and transgender survey: Results at a glance [Website]. Retrieved from: 
http://fra.europa.eu/en/publication/2013/eu-lgbt-survey-european-union-lesbiangay-bisexual-and-transgender-survey-results

Fergusson, D. M., Horwood, J., \& Beautrais, A. L. (1999). Is sexual orientation related to mental health problems and suicidality in young people? Archives of General Psychiatry, 56(10), 876-880.

Fox, J. (1997). Poetic medicine: The healing art of poem-making. New York, NY: Putnam.

Furman, R. (2003). Exploring step-fatherhood through poetry. Journal of Poetry Therapy, 16(2), 91-96.

Furman, R. (2004a). The prose poem as a means of exploring friendship: Pathways to reflection. Journal of Poetry Therapy, 17(2), 91-100.

Furman, R. (2004b). Exploring friendship loss through poetry. Journal of Loss and Trauma, 9(1), 181-187.

Furman, R., Lietz, C., \& Langer, C. L. (2006). The research poem in international social work: Innovations in qualitative methodology. International Journal of Qualitative Methods, 5(3), 1-8.

Gallardo, H. L., Furman, R., Kulkarni, S. (2009). Explorations of depression: Poetry and narrative in autoethnographic qualitative research. Qualitative Social Work, 8(3), 287-304.

Gilman, S. E., Cochran, S. D., Mays, V. M., Hughes, M., Ostrow, D., \& Kessler, R. C. (2001). Risk of psychiatric disorders among individuals reporting same-sex sexual partners in the National Comorbidity Survey. American Journal of Public Health, 91(6), 933-939.

Glesne, C. (1997). That rare feeling: Re-presenting research through poetic transcription. Qualitative Inquiry, 3(2), 202-221.

Hatzenbuehler, M. (2009). How does sexual minority stigma "get under the skin"? A psychological mediation framework. Psychological Bulletin, 135(5), 707-730.

Hatzenbuehler, M. (2011). The social environment and suicide attempts in lesbian, gay, and bisexual youth. Pediatrics, 127(5), 896-903.

Hatzenbuehler, M. L., Nolen-Hoeksema, S., \& Erickson, S. J. (2008). Minority stress predictors of HIV risk behavior, substance use, and depressive symptoms: Results from a prospective study of bereaved gay men. Health Psychology, 27(4), 455-462. doi: 10.1037/0278-6133.27.4.455 
The Henry J. Kaiser Family Foundation. (2001). Inside-Out: A report on the experiences of lesbians, gays, and bisexuals in American and the public's views on issues and policies related to sexual orientation. Menlo Park, CA: Author. Retrieved from: http://www.lgbtdata.com/uploads/1/0/8/8/10884149/ds020_ksso_report.pdf

Herek, G. M. (2009). Hate crimes and stigma-related experiences among sexual minority adults in the Unites States: Prevalence estimates from a national probability sample. Journal of Interpersonal Violence, 24(1), 54-74.

Herek, G. M., Gillis, J. R., \& Cogan, J. C. (1999). Psychological sequelae of hate crime victimization among lesbian, gay, and bisexual adults. Journal of Consulting and Clinical Psychology, 67(6), 945-951.

Hesse-Biber, S. N. (2013). Feminist research in practice: A primer $\left(2^{\text {nd }}\right.$ ed. $)$. Thousand Oaks, CA: Sage.

Jones, E. E., Farina, A., Hastorf, A., Markus, H., Mella, D., \& Scott, R. (1984). Social stigma: The psychology of marked relationships. New York: Freeman and Company.

Jorm, A. F., Korten, A. E., Rodgers, B., Jacomb, P. A., \& Christensen, H. (2002). Sexual orientation and mental health: Results from a community survey of young and middle-aged adults. British Journal of Psychiatry, 180(5), 423-427.

Kovach, M. (2010). Indigenous methodologies: Characteristics, conversations, and contexts. Toronto, ON: University of Toronto Press.

Krøjer, J., \& Hølge-Hazelton, B. (2008). Poethical: Breaking ground for reconstruction. Internal Journal of Qualitative Studies in Education, 21(1), 27-33. doi:10.1080/09518390701768773

Langer, C. L., \& Furman, R. (2004). Exploring identity and assimilation: Research and interpretive poems. Forum: Qualitative Social Research, 5(2) [Online]. Retrieved from:

http://nbn-resolving.de/urn:nbn:de:0114-fqs040254

Leavy, P. (2009). Method meets art: Arts-based research practice. New York, NY: Guilford Press.

Mays, V. M. \& Cochran, S. D. (2001). Mental health correlates of perceived discrimination among lesbian, gay, and bisexual adults in the United States. American Journal of Public Health, 91(1), 1869-1876.

Mazza, N. (2003). Poetry therapy: Theory and practice. New York, NY: Routledge. 
Meyer, I. H. (1995). Minority stress and mental health in gay men. Journal of Health and Social Behavior, 36(1), 38-56.

Meyer, I. H. (2003). Prejudice, social stress, and mental health in lesbian, gay, and bisexual populations: Conceptual issues and research evidence. Psychological Bulletin, 129(5), 674-697.

Meyer, I. H., Schwartz, S., \& Frost, D. M. (2008). Social patterning of stress and coping: Does disadvantaged social statuses confer more stress and fewer coping resources? Social Science \& Medicine, 67(3), 368-379. doi: 10.1016/j.socscimed.2008.03.012

Patterson, C. J. (2000). Family relationships of lesbians and gay men. Journal of Marriage and Family, 62(4), 1052-1070.

Pelias, R. J. (2005). Performative writing as scholarship: An apology, an argument, and anecdote. Cultural Studies Critical Methodologies, 5(4), 415-424.

Plöderl, M., \& Fartacek, R. (2005). Suicidality and associated risk factors among lesbian, gay, and bisexual compared to heterosexual adults. Suicide and Life Threatening Behavior, 35(6), 661-670.

Richardson, L. (1994). Nine poems: Marriage and the family. Journal of Contemporary Ethnography, 23(1), 3-13.

Richardson, L. (2002). Poetic representation of interviews. In J. F. Gubrium \& J. A. Holstein (Eds.), Handbook of interview research: Context and method (pp. 877891). Thousand Oaks, CA: Sage.

Safren. S. A., \& Heimberg, R. G. (1999). Depression, hopelessness, suicidality, and related factors in sexual minority and heterosexual adolescents. Journal of Consulting and Clinical Psychology, 67(6), 859-866.

Sandfort, T. G. M., de Graaf, R., Van Bijl, R., \& Schnabel, P. (2001). Same-sex sexual behavior and psychiatric disorders. Archives of General Psychiatry, 58(1), 85-91.

Sandfort, T. G. M., Bakker, F., Schellevis, F. G., and Vanwesenbeek, I. (2006). Sexual orientation and mental and physical health status: From a Dutch population survey. Journal of Public Health, 96(6), 1119-1125.

Scales Rostosky, S., Riggle, E. D. B., Horne, S. G., \& Miller, A. D. (2009). Marriage amendments and psychological distress in lesbian, gay, and bisexual (LGB) adults. Journal of Counseling Psychology, 56(1), 56-66. doi: 10.1037/a0013609 
Thoits, P. A. (1999). Sociological approaches to mental illness. In T. L. Scheid \& A. V. Horwitz (Eds.), A handbook for the study of mental health (pp. 121-138). Cambridge, UK: Cambridge University Press.

Thoma, B. C., \& Huebner, D. M. (2013). Health consequences of racist and antigay discrimination for multiple minority adolescents. Cultural Diversity and Ethnic Minority Psychology, 19(4), 404-413. doi: 10.1037/a0031739

Wordsworth, W. (2001). Preface to Lyrical ballads. In C. W. Eliot (Ed.), Great books online: Harvard classics Vol. 39. Prefaces and prologues: To famous books [Online]. Bartleby.com, Inc. (original work published 1800). Retrieved from: http://www.bartleby.com/39/36.html 